\title{
Role of Plant-Microbe Interactions in Rhizoremediation of Petroleum Product-Polluted Nigerian Soils
}

\author{
Umeaku Chinyelu Nkiru ${ }^{1}$, Okpokwasili Gideon Chijioke ${ }^{2}$, Iwuala Moses ${ }^{3}$, \\ Nwigwe Harriet Chinyelu ${ }^{3}$, Chris-Umeaku Chiamaka Ijeoma ${ }^{4}$ \\ ${ }^{1}$ Department of Microbiology, Chukwuemeka Odumegwu Ojukwu University, Uli, Anambra, Nigeria \\ ${ }^{2}$ Department of Microbiology, University of Port Haccourt, Choba, Rivers, Nigeria \\ ${ }^{3}$ Department of Biotechnology, Federal University of Technology, Owerri, Nigeria \\ ${ }^{4}$ Department of Biochemistry, Chukwuemeka Odumegwu Ojukwu University, Uli, Anambra, Nigeria
}

Email address:

chimeaku@yahoo.com (U. C. Nkiru)

\section{To cite this article:}

Umeaku Chinyelu Nkiru, Okpokwasili Gideon Chijioke, Iwuala Moses, Nwigwe Harriet Chinyelu, Chris-Umeaku Chiamaka Ijeoma. The Role of Plant-Microbe Interactions in Rhizoremediation of Petroleum Product-Polluted Nigerian Soils. Frontiers in Environmental Microbiology. Vol. 5, No. 2, 2019, pp. 36-47. doi: 10.11648/j.fem.20190502.11

Received: June 13, 2018; Accepted: March 8, 2019; Published: April 12, 2019

\begin{abstract}
Plant-microbe interactions in petroleum product-contaminated soils were examined under field conditions, to analyze the effects of environmental factors on rhizoremediation. Different plant types (elephant grass, cassava, carpet grass, Indian bamboo, fern, palm and a mixture of these plants) were considered. The abundance of effective indigenous microorganisms (EIM) and remediation time were also considered. Eight soil samples were collected from crude oilcontaminated sites of Ogoni, Rivers State, Nigeria. Total viable counts were taken using spread plate methods. Hydrocarbon utilizing microorganisms using mineral salt agar with crude oil vapor phase gave counts in the range of $10^{2}-10^{8}$. Gas Chromatographic - FID methods gave results of 9 field samples for TPH to range from $0.96 \mathrm{mg} / \mathrm{kg}$ for control to $4,650 \mathrm{mg} / \mathrm{kg}$ for oil well 3 without vegetation. Polyaromatic hydrocarbon (PAH) of 9 field samples ranged from $0.26 \mathrm{mg} / \mathrm{kg}$ for control to $30.066 \mathrm{mg} / \mathrm{kg}$ depending on the extent of pollution of the site. Mixed plant population showed abundance of EIM $\left(10^{8}\right)$ and greater TPH and PAH removal. The effect of time on the concentration of TPH and PAH in the different samples show that significant difference exist, $\mathrm{P}$ - value $=0.420$. Microbial counts are significantly different over time, also microbial counts are significantly different in the different samples $(\mathrm{F}$-value $=3.15,2.76,2.53,2.1,1.92$ and 1.7) for rows, columns and layers. Local Nigerian plants could promote rhizoremediation of crude oil polluted soils.
\end{abstract}

Keywords: Rhizoremediation, Microorganisms, TPH, PAH, Microbial Counts, Gas Chromatographic, Remediation

\section{Introduction}

\section{Background Information}

Rhizoremediation is an elegant form of bioremediation that seeks to harness light energy via plants to biostimulate pollutant degradation by indigenous soil microbial community. Exploration and production of crude oil in Nigeria are carried out in the oil-rich Niger Delta region (Bayelsa, Rivers, and Delta) and Imo states. Over $80 \%$ of the country's oil comes from this ecological zone and its surrounding offshore areas [1]. Within the Delta, the numerous national deposits (oil fields), tank farms, flow stations, pipelines, tankers and loading jetties constantly provide potential sources of oil pollution [8]. Large scale pollution of both the terrestrial and aquatic environments as a result of activities of the oil industries have been documented ([23]; [8]). In addition to seepage and human activities, oil spills in Nigeria occur due to a number of other causes such as corrosion of pipelines and tankers. Infrastructure may be old and lack regular inspection and maintenance. Apart from ecological and health problems, there are significant financial repercussions associated with the release of these compounds into the soil. Contaminated soil generally remains toxic until suitable clean-up has occurred, a process that may take 
substantial time and money. Although the physical and chemical processes such as dispersion, dilution, sorption, volatilization and abiotic transformation are important means of hydrocarbon elimination, biodegradation is most often the primary mechanism for contaminant clean-up. Plants and their associated microorganisms are efficient for decontamination of crude oil-polluted soils [15]. Rhizoremediation utilizes the absorption, stabilization and rhizosphere effect of the plant to remediate polluted soils. Oil spills result in an imbalance in the carbon-nitrogen ratio at the spill site, because crude oil is essentially a mixture of carbon and hydrogen. This causes the nitrogen deficiency in an oil soaked soil, which retards the growth of bacteria and utilization of carbon source [11]. Furthermore, large concentration of biodegradable organics in the top layer of agricultural soils deplete oxygen reserves in the soil and slow down the rate of oxygen diffusion to deeper layers [1]. Rhizoremediation draws upon the fields of rhizosphere ecology and microbial biodegradation. Although accumulating studies show that rhizoremediation is a viable treatment option for petroleum hydrocarbon [1], this technology is still under-valued and under-utilized. The primary reason is the lack of consensus between study findings. Plant species vary greatly in their ability to increase the hydrocarbon degradation capacity of soil microbial communities ([16]; [30]; [7]). The goal of this research is to evaluate the degradation potential of rhizosphere microorganisms of some local Nigerian plants in the remediation of crude oil-polluted soils with a view of using them in rhizoremediation of crude oil-polluted soils.

\section{Materials and Methods}

\subsection{Designation of Field Samples from Ogoni}

8 samples were collected from the crude oil-polluted sites as described above, and designated;

$\begin{array}{lll}\text { A } & - & \text { Non rhizosphere oil well site at Kpopie } \\ \text { B } & - & \text { Palm rhizosphere } \\ \text { C } & - & \text { Indian bamboo rhizosophere } \\ \text { D } & - & \text { Mixed population } \\ \text { E } & - & \text { Oil well 3 korokoro - no vegetation } \\ \text { F } & - & \text { Oil well 3 korokoro - with elephant grass } \\ \text { G } & - & \text { Grass rhizosphere } \\ \text { H } & - & \text { Fern rhizosphere } \\ \text { Control } & - & \text { Control }\end{array}$

All samples were collected on same day. They were collected at $15 \mathrm{~cm}$ depth from the soil surface with sterile cellophane bags, the cellophane bags were sterilized by washing with $70 \%$ ethanol, followed with a minimum of five rinses with sterile water. These were carefully labeled and transported to the laboratories for analysis.

\subsection{Collection of Soil Samples}

Rhizosphere samples were collected from the root zones of plants in the plots at $15 \mathrm{~cm}$ depth. The soil samples were sieved and immediately taken to the laboratory for physicochemical analysis. Roots were shaken to dislodge loose soil. Rhizosphere soil was also sent to the laboratory for hydrocarbon analysis. Rhizosphere soil from all sites were archived at $-4^{\circ} \mathrm{C}$ as standby or soil sample bank. Washed roots were dried at room temperature. Microbiological analysis commenced $24 \mathrm{hrs}$ - 36hrs after collection.

\subsection{Physico-chemical Analysis}

The following physico-chemical parameters were analyzed, $\mathrm{pH}$, total organic carbon, percentage organic matter, total nitrogen, magnesium $/ \mathrm{kg}$, microbial respiration, nitrate, phosphate, moisture content, $\mathrm{Pb}, \mathrm{Cu}^{2+}, \mathrm{Al}^{3+}, \mathrm{Fe}^{2+}, \mathrm{Cd}$, and $\mathrm{Hg}$ according to Methods of APHA [3].

\subsubsection{Determination of $\mathrm{pH}$}

$\mathrm{pH}$ of saturated paste of soil samples were analyzed using the calibrated $\mathrm{pH}$ meter, scientific water quality multimeter850081 model was used.

\subsubsection{Nitrate Determination}

Nitrate in the samples was determined by the cadmium reduction method (APHA 4500-NO3E) using cecil-ce 1021(1000 series) ultraviolet visible spectrophotometer at wavelength of $543 \mathrm{~nm}$.

\subsubsection{Phosphate Determination}

Phosphate in the samples was determined by the 4500-PD test method. A colorimeter method based on a blue complex induced by the addition of stannous chloride. The samples were analyzed at a wavelength of $690 \mathrm{~nm}$ with cecil-ce 102(1000 series) ultra violet visible spectrophotometer.

\subsubsection{Determination of Total Organic Carbon (TOC)}

The TOC of the sample was determined using the Walkey and Black wet oxidation method of APHA [3]. About $0.5 \mathrm{~g}$ of each of the samples was weighed into a $250 \mathrm{ml}$ conical flask. $10 \mathrm{ml}$ of $1 \mathrm{~N}$ potassium dichromate solution and $20 \mathrm{ml}$ of concentrated sulfuric acid were added. The mixtures were shaken thoroughly for about 2 minutes and were allowed to stand for 10 minutes on an asbesto mat. $200 \mathrm{ml}$ of distilled water and $10 \mathrm{ml}$ of phosphoric acid were then added and mixed gently. The resultant mixtures were titrated with $0.5 \mathrm{M}$ ferrous ammonium sulphate solution using $1 \mathrm{M}$ of diphenylamine solution as indicator. A blank was set up, manual titration was used in the experimental sample. The percentage carbon in the samples were calculated thus;

$$
M X \frac{\mathrm{V} 1-\mathrm{V} 2}{\mathrm{~W}} \times 0.30 \times \mathrm{CF}
$$

Where:

$\mathrm{M}$ is the molarity of the $\mathrm{FeSO}_{4}$ solution (from blank titration),

$\mathrm{V} 1$ is the volume $(\mathrm{mL})$ of $\mathrm{FeSO}_{4}$ required in blank titration,

$\mathrm{V} 2$ is the volume $(\mathrm{mL})$ of $\mathrm{FeSO}_{4}$ required in actual titration,

$\mathrm{W}$ is the weight $(\mathrm{g})$ of the oven-dried soil sample and 
$\mathrm{CF}$ is the correction factor. The $\mathrm{CF}$ is a compensation for the incomplete oxidation and is the inverse of the recovery. This CF was set by Walkley and Black as 1.32 (recovery of $76 \%$ ).

Automated methods were used for the field samples. The automated method made use of the gas chromatograph (GC) attached to a flame ionization detector. The $\mathrm{CO}_{2}$ was first converted to $\mathrm{CH}_{4}$ by passing the evolved gas through the heated aluminum coated with nickel in a hydrogen enriched atmosphere. The results were read from the chromatogram using USEPA [33] methods. The percentage carbon in the samples were calculated thus;

\subsubsection{Determination of Moisture Content}

$10.0 \mathrm{~g}+0.001 \mathrm{~g}$ of each of the samples was weighed into a pre-tarred crucible. The crucible and the soil sample were then heated in an oven at $105^{\circ} \mathrm{C}$ (degree Celsius) for 2 hours. The crucible was then transferred into a desiccator and weighed. This later process was continued until a constant weight was obtained. The percentage moisture was calculated.

$$
\text { Moisture content } \%=\frac{\mathrm{W} 2-\mathrm{W} 3}{\mathrm{~W} 2-\mathrm{W} 1} \times \frac{100}{1}
$$

Where $\% \mathrm{~W}=$ Percentage of Moisture in the sample.

$\mathrm{W} 1=$ Weight of container with lid.

W2 = Weight of container with lid and sample before Drying.

$\mathrm{W} 3$ = Weight of container with lid and sample after Drying.

\subsubsection{Total Nitrogen}

Methods of Kjeldahl which involves digestion of the samples to convert all nitrogenous compounds into ammonium was used. Soil for analysis was finely ground to pass through $60-80 \mathrm{~mm}$ mesh-sieve. $25 \mathrm{~g}$ of soil was weighed into a dry micro Kjeldahl flask and $20 \mathrm{ml}$ of distilled water was added. The flask was swirled for few minutes. A mixture of $10 \mathrm{~g}$ of $\mathrm{K}_{2} \mathrm{SO}_{4}, 1 \mathrm{~g}$ of $\mathrm{CuSO}_{4}, 1 \mathrm{~g}$ of selenium and $30 \mathrm{ml}$ of conc. $\mathrm{H}_{2} \mathrm{SO}_{4}$ was added to the flask. The flask was gently heated continuously, then more strongly until the acid was boiled. Heating was continued until the organic acid was destroyed (the solution was clear light yellow to gray). The flask was allowed to cool until crystals appeared. The content of the flask was transferred into a $200 \mathrm{ml}$ volumetric flask washing 4 times with $\mathrm{NH}_{3}$ free water. Distillation: $10 \mathrm{ml}$ of the solution was pipetted into a Kjeldahl flask, $25 \mathrm{ml}$ of $4 \%$ boric acid and 4 drops of bromocrysol green methyl red indicator ( $\mathrm{M}$ and Zuazaga indicator) was added into a $100 \mathrm{ml}$ Erlenmeyer flask. The outlet was connected to the condenser so that the tip of the outlet (glass-tube) was just beneath the boric acid, $10 \mathrm{ml}$ of $40 \% \mathrm{NaOH}$ was allowed to slide slowly down the side of the distillation flask. $50 \mathrm{ml}$ of the distillate was collected for $5 \mathrm{mins}$.

Observed $\mathrm{N}_{2}$ volume was calculated thus:

$$
\text { Vo. }=\mathrm{R}_{2}-\mathrm{R}_{1}
$$

where $\mathrm{Vo}=$ Observed $\mathrm{N}_{2}$ Volume $(\mathrm{ml})$

$\mathrm{R}_{1}=$ Initial count reacting

$\mathrm{R}_{2}=$ Final count reacting

Corrected $\mathrm{N}_{2}$ volume $(\mathrm{ml})=\mathrm{Vc}$

Automated methods using GC were also utilized in this study.

\subsection{Microbiology}

\subsubsection{Culturable Microbiological Analysis}

Entire plants were placed on ice pack for transport back to the laboratory and were stored at the temperature of -4 degree Celsius until process and analysis (within $36 \mathrm{hrs}$ of sampling for soil samples and $72 \mathrm{hr}$ for endophytic samples). Soil from each plant and from each site was serially diluted in distilled water. Total heterotrophic bacteria were enumerated using the spread plate method on nutrient agar according to methods of Cheesbrough [6]. One gram of each of the soil sample was weighed and transferred into $250 \mathrm{ml}$ flask containing $9 \mathrm{ml}$ of sterile distilled water. The suspensions were shaken intermittently for about 30 minutes. Each solution was allowed to stand for 1 hour after which the suspension was decanted into another $250 \mathrm{ml}$ flask. Ten-fold serial dilution was set up from the soil suspension. $0.1 \mathrm{ml}$ of the one $i n 10^{2}$, $10^{3}, 10^{4}, 10^{5}, 10^{6}, 10^{7}$, and $10^{8}$ were spread in duplicate. Freshly prepared nutrient agar was poured and allowed to set. This was used as control. Plates were incubated at room temperature for $24 \mathrm{hrs}$. Total plate counts were carried out using the colony counter. Organisms were subcultured in sterile nutrient agar for total heterotrophs. Mineral salt agar was used for hydrocarbon utilizing organism (HUO) according to methods of Okpokwasili, and Odokuma [22]. Anaerobic organisms were cultivated using petri plates sealed with vaseline and incubating under anaerobic condition (methods of Kirk et al., [12]). Sabaraud dextrose agar (SDA) was used for fungi culture. These were incubated at room temperature for 3-5 days. Fungal atlas was used in identifying the organisms.

\subsubsection{Enumeration of Hydrocarbon Utilizing Bacteria}

Culturable hydrocarbon degraders, also known as hydrocarbon degrading bacteria (HUB) were assayed for. Here crude oil was used as the sole source of energy and carbon. Sterilized crude oil was used to soak sterilized filter paper. This was placed in the lid of inverted plates. The plates were incubated at room temperature for 6 days and HUB were counted ([21]; [24]). Bushnell Haas (BH) mineral salt agar (per litre: $0.29 \mathrm{~g} \mathrm{MgSO}_{2} .7 \mathrm{H}_{2} \mathrm{O}, 0.02 \mathrm{~g} \mathrm{CaCl}_{2} .2 \mathrm{H}_{2} \mathrm{O}, 1.0 \mathrm{~g}$ $\mathrm{kH}_{2} \mathrm{PO}_{4}, 1.0 \mathrm{~g}\left(\mathrm{NH}_{4}\right), \mathrm{HPO}_{4}, 1.0 \mathrm{~g} \mathrm{KNO}_{3}, 0.05 \mathrm{FeCl} .6 \mathrm{H}_{2} \mathrm{O}$, $\mathrm{pH} 7$ ) was used to culture the serially diluted samples. Plates were incubated in the dark at room temperature [25]. Nystatin and Streptomycin were added for selectivity for bacteria and fungi respectively.

\subsubsection{Characterization and Biochemical Identification of Isolates}

Pure isolates were examined for their cultural appearance. Endospore, acid fast and Grams staining techniques were 
performed to establish the cell morphology of the isolates. Motility, citrate utilization, oxidase, catalase, indole and coagulase tests were carried out according to methods of (Umeaku[34]; Talaro, and Talaro, [32]; Cheesbrough [6]). Microbial identification was performed using the keys provided by Bergey's Manual of Determinative Bacteriology (1994).

\subsubsection{Endophytic Microbial Community}

Rinced roots were surface-disinfected by sequential washing with $95 \%$ ethanol and $5.25 \%$ sodium hypochlorite, followed by a minimum of 5 rinses with sterile water. To assess surface sterility $100 \mu$ aliquot of the samples of final rinse water were spread on $1 / 10$ th TSA plates. Endophytic extracts were produced by macerating $2.5 \mathrm{~g}$ surface-sterile root from each treatment plot in replicate $22.5 \mathrm{ml}$ monopotasium phosphate (MPP) buffer $\left(0.65 \mathrm{~g} \mathrm{~K}_{2} \mathrm{HPO}, 0.10 \mathrm{~g}\right.$ $\mathrm{MgSO}_{4}$ per litre of water) using a sterile mortar and pestle. Root extracts were serially diluted in MPP. Serial 10-fold dilutions of these were used for culturable microbial enumeration.

\subsection{Gas Chromatographic Analysis}

Gas chromatographic analysis was used for TPH and PAH tests. Residual total petroleum hydrocarbons (TPHs) and polycylic aromatic hydrocarbons PAHs) were extracted from the soil samples collected from Ogoni and quantified using gas chromatograph-flame ionization detector (GC- FID) according to the methods of ASTDM 3912(2013) and USEPA [33]. The collected samples were air dried and extracted using hexane $(5 \mu \mathrm{g})$. The samples were injected into the gas chromatograph (using a microsyringe) through a rubber septum into a flash vaporizing port at the head of the column. The temperature of the sample port is usually about $50^{\circ} \mathrm{C}$ higher than the boiling point of the least volatile component of the sample. Inside the GC the carriers' gas is allowed to move each analyte through the column. Each analyte will require a different amount of time to pass through the column. The sample's outlet stream was monitored with a detector.

\subsection{Molecular Biologic Analysis}

\subsubsection{Plasmid Extraction: TENS - Mini Prep}

$1.5 \mathrm{ml}$ of overnight culture from each sample was spinned for one min in a microcentrifuge to pellet the cells. The supernatants were gently decanted, leaving 50 $100 \mu 1$ together with cell pellet, these were vortexed at high speed to re-suspend cells completely. $300 \mu$ of TENS (a mixture of Tris $25 \mathrm{mM}$, EDTA $10 \mathrm{mM}, \mathrm{NaOH} 0$. IN and SDS $0.5 \%$ ) was added to each tube. The tubes were inverted 3-5 times until the mixture became sticky. Samples were set on ice to prevent degradation of chromosomal DNA. $150 \mu \mathrm{l}$ of 3.0 sodium acetate $\mathrm{pH} 5.2$ was added to each tube and vortexed to mix completely. The content of each tube was spinned for 5 mins in micro centrifuge to pellet cell debris. The supernatants were transferred into fresh tubes, properly mixed with $900 \mu 1$ of ice-cold absolute ethanol. These were spinned for $10 \mathrm{mins}$ to pellet plasmid DNA -white pellets. The supernatants were discarded, and pellets were rinsed twice in $1 \mathrm{ml}$ of $70 \%$ ethanol. The pellets were re-suspended in $20-40 \mu 1$ of $\mathrm{TE}$ buffer or distilled water for further use.

\subsubsection{Preparation of Agarose Electrophoresis}

For $100 \mathrm{ml}$ of Tris borate EDTA (TBE), $0.80 \mathrm{~g}$ of agarose was weighed. This was melted in the microwave oven for 2 mins, $10 \mathrm{sec}$. The electrophoretic tank was set up. Then, the agarose was brought out of the oven and allowed to cool. Few drops of etidium bromide were added after preparing the gel. $10 \mathrm{ml}$ of the extracted DNA was mixed with $5 \mathrm{ml}$ of bromothymol blue and kept aside. The TBE/Gel was poured onto the electrophoretic tank. Micropipette was used to load the DNA mixture onto the wells of the electrophoretic tank.

\subsection{Statistical Analysis}

The major statistical technique used in this study for the analysis of the collected data is Analysis of Variance (ANOVA). The ANOVA being basically an arithmetic method for breaking down the total variation of the collected data into components representing the sources of variations recognized in the study. The sources of variation were determined by the criteria used to classify the observations. In this study, only one-way, two-way and three-way Analysis of Variance were used. Tukey's pairwise comparison was utilized. Minitabs were used to present the data.

\section{Results}

Table 1 - Presents the physicochemical parameter in the various soil samples obtained from the crude oil-polluted environment of Ogoni, Nigeria.

Table 2 - Describes the mean value of TPH in the various sites.

Figure 1 Presents the mean value of TPH in the various study sites.

Figure 2 - Presents the mean value of PAH in the various sites.

Table 1. Physiochemical parameters of the various soil samples from crude oil - polluted environment, Ogoni, Niger Delta

\begin{tabular}{|c|c|c|c|c|c|c|c|c|c|c|c|}
\hline $\mathbf{S} / \mathbf{N}$ & Sample code & $\mathbf{p H}$ & $\begin{array}{l}\text { moisture } \\
\text { content } \%\end{array}$ & $\mathrm{~N}_{2}(\%)$ & $\begin{array}{l}\mathrm{Cu}^{2+} \\
(\mathrm{mg} / \mathrm{Kg})\end{array}$ & $\begin{array}{l}\mathbf{P b}^{2+} \\
(\mathrm{m} / \mathrm{kg})\end{array}$ & $\begin{array}{l}\mathrm{Al}^{3+} \\
(\mathrm{mg} / \mathrm{kg})\end{array}$ & $\begin{array}{l}\mathrm{Fe}^{2+} \\
\text { (mgkg) }\end{array}$ & $\begin{array}{l}\text { Cd } \\
\text { (mgkg) }\end{array}$ & $\begin{array}{l}\mathrm{Hg} \\
(\mathrm{mg} / \mathrm{kg})\end{array}$ & $\begin{array}{l}\text { Cumulative } \\
\mathrm{Co}_{2}-21 \text { days }\end{array}$ \\
\hline 1 & A & 5.78 & 16 & 0.210 & Trace & 78.27 & 4.29 & 210.26 & 0.022 & $<0.001$ & 183.9 \\
\hline 2 & B & 4.93 & 26 & 0.455 & Trace & 78.27 & 10.72 & 430.18 & 0.074 & $<0.001$ & 658.9 \\
\hline 3 & $\mathrm{C}$ & 5.52 & 38 & 0.315 & 49.85 & 326.15 & 26.44 & 514.77 & 0.048 & $<0.001$ & 766.7 \\
\hline
\end{tabular}




\begin{tabular}{|c|c|c|c|c|c|c|c|c|c|c|c|}
\hline $\mathbf{S} / \mathbf{N}$ & Sample code & pH & $\begin{array}{l}\text { moisture } \\
\text { content } \%\end{array}$ & $\mathbf{N}_{2}(\%)$ & $\begin{array}{l}\mathrm{Cu}^{2+} \\
(\mathrm{mg} / \mathrm{Kg})\end{array}$ & $\begin{array}{l}\mathrm{Pb}^{2+} \\
(\mathrm{m} / \mathrm{kg})\end{array}$ & $\begin{array}{l}A^{3^{3+}} \\
(\mathrm{mg} / \mathrm{kg})\end{array}$ & $\begin{array}{l}\mathrm{Fe}^{2+} \\
(\mathrm{mgkg})\end{array}$ & $\begin{array}{l}\begin{array}{l}\text { Cd } \\
(\mathrm{mgkg})\end{array} \\
\end{array}$ & $\begin{array}{l}\mathrm{Hg} \\
(\mathrm{mg} / \mathrm{kg})\end{array}$ & $\begin{array}{l}\text { Cumulative } \\
\mathrm{Co}_{2}-21 \text { days } \\
\end{array}$ \\
\hline 4. & $\mathrm{D}$ & 5.26 & 12 & 0.455 & 72.21 & 208.73 & 37.88 & 554.6 & 0.062 & $<0.001$ & 185.9 \\
\hline 5. & $\mathrm{E}$ & 6.14 & & 0.420 & 43.51 & 295.71 & 58.60 & 882.11 & 0.086 & $<0.001$ & 183.7 \\
\hline 6. & $\mathrm{~F}$ & 5.23 & 28 & 0.490 & 37.77 & 513.14 & 59.32 & 827.73 & 0.138 & $<-.001$ & 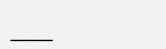 \\
\hline 7. & G & 5.51 & 22 & 0.595 & 12.69 & 143.50 & 14.29 & 362.51 & 0.010 & $<0.001$ & 542.3 \\
\hline 8. & $\mathrm{H}$ & 5.62 & 32 & 0.560 & 16.92 & 200.04 & 22.15 & 561.89 & 0.096 & $<0.001$ & 566.5 \\
\hline 9. & $\mathrm{CO}$ & 5.14 & & 0.525 & 25.98 & 173.94 & 34.30 & 604.19 & $<0.001$ & $<0.001$ & 210.1 \\
\hline 10 & $\begin{array}{l}\text { Normal } \\
\text { Value }\end{array}$ & 6.75 & & & $15-30$ & $7-42$ & & 50 & & & \\
\hline
\end{tabular}

A: Non-rhizosphere soil,

B: Palm rhizophere

C: Indian bamboo rhizophere,

D: Mix plant rhizophere,

E: Oil well 3 korokoro- no vegetation,

F: Oil well 3 with elephant grass,

G: Grass rhizophere,

$\mathrm{H}$ : Fern rhizophere,

CO: Control.

Table 2. Microbial population changes during biodegradation of crude oil polluted farmlands in Ogoni, Niger Delta.

\begin{tabular}{|c|c|c|c|c|c|c|}
\hline Sampling site/ code & TPH mg /kg & PAH mg / kg & ТНВ & HUB & FC & HUF \\
\hline A. Non Rhizosphere & 313.25 & 2.949 & $2.3 \times 10^{5}$ & $1.9 \times 10^{4}$ & $1.0 \times 10^{4}$ & $2.6 \times 10^{3}$ \\
\hline B. Palm Rhizosphere & 1551.67 & 16.176 & $4.7 \times 10^{6}$ & $5.6 \times 10^{5}$ & $7.0 \times 10^{5}$ & $4.9 \times 10^{3}$ \\
\hline D. Mixed plant population & 56 & 0.314 & $1.6 \times 10^{7}$ & $4.5 \times 10^{8}$ & $1.6 \times 10^{6}$ & $1.35 \times 10^{5}$ \\
\hline E. Oil well 3 korokoro No weight & $4,650.13$ & 30.066 & $1.0 \times 10^{5}$ & $1.0 \times 10^{4}$ & $1.0 \times 10^{5}$ & $2.4 \times 10^{3}$ \\
\hline F. Oil well 3 korokoro oil- elephant grass & $3,538.13$ & 24.593 & $5.2 \times 10^{6}$ & $2.5 \times 10^{6}$ & $6.0 \times 10^{5}$ & $2.80 \times 10^{3}$ \\
\hline G. Grass Rhizosphere & $1,520.92$ & 15.623 & $1.3 \times 10^{6}$ & $2.9 \times 10^{7}$ & $6.0 \times 10^{5}$ & $1.8 \times 10^{3}$ \\
\hline H. Fern Rhizosphere & 415.92 & 3.839 & Confluent & $1.58 \times 10^{8}$ & $1.0 \times 10^{6}$ & $1.56 \times 10^{2}$ \\
\hline Control & 53.96 & 0.265 & $2.5 \times 10^{4}$ & $7.0 \times 10^{4}$ & $30.0 \times 10^{2}$ & $1.4 \times 10^{2}$ \\
\hline
\end{tabular}

TPH: Total petroleum hydrocarbon

PAH: Polyaromatic hydrocarbon

THB: Total heterotrophic bacteria

HUB: Hydrocarbon utilizing bacteria

FC: Fungal Count

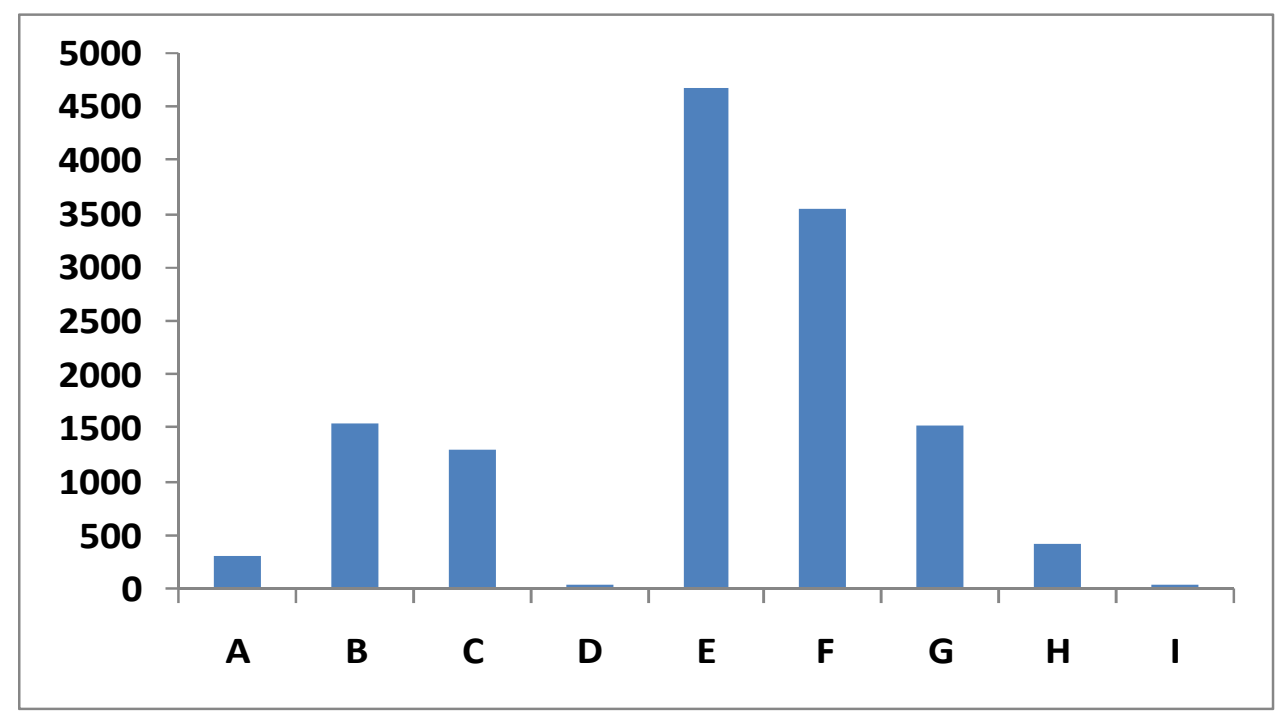

Figure 1. Mean values of TPH in the various sites. 


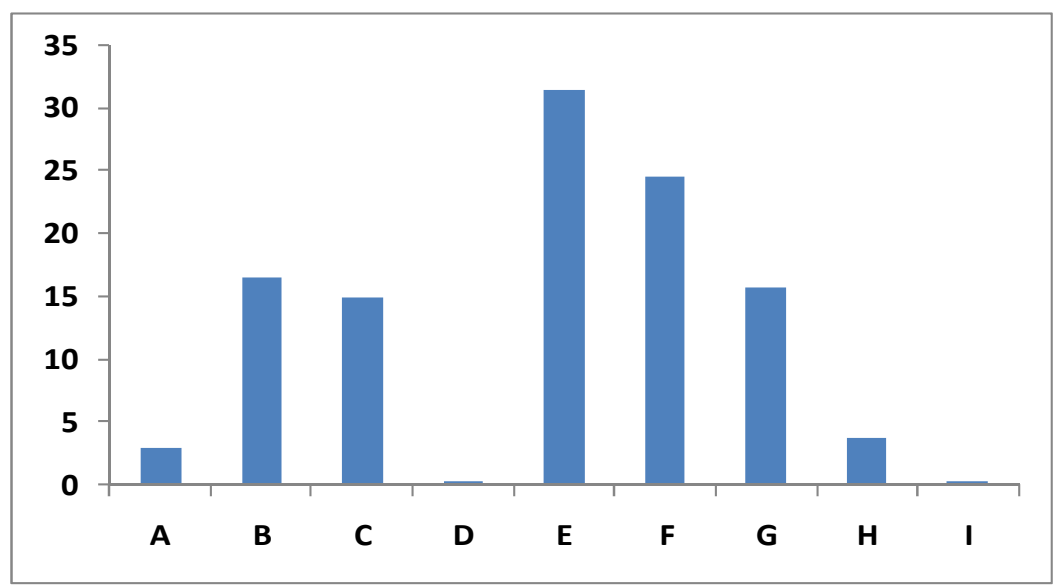

Figure 2. Mean values of PAH in the various sites.

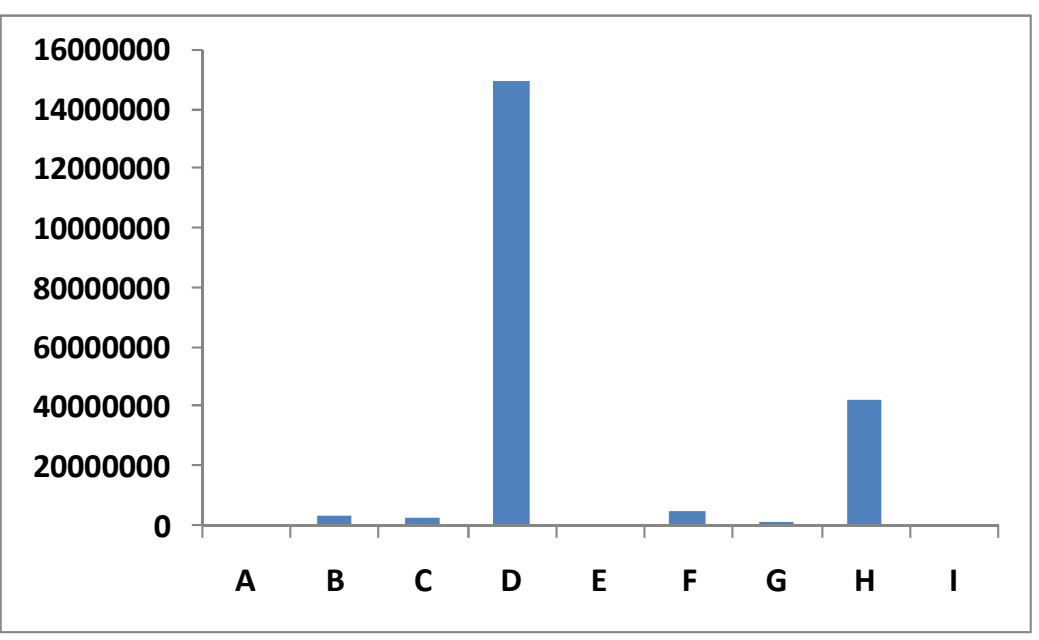

Figure 3. Mean counts of THB in the various sites.

Table 3 - Describes the biochemical characterization of the isolates while table 4 is the biochemical characterization of the crude oil degraders.

Table 5 - Demonstrates the succession observed in the study.

Figure 4 - Plasmid profile of some isolates.

Table 3. Biochemical characteristics of heterotrophic bacterial isolates from crude oil polluted soil.

\begin{tabular}{|c|c|c|c|c|c|c|c|c|}
\hline Isolate & $\begin{array}{l}\text { Cultural } \\
\text { Characterization }\end{array}$ & $\begin{array}{l}\text { Morphological } \\
\text { Characteristics }\end{array}$ & Gram stain & Spore stain & Coagulase & Catalase & Oxidase & Urease \\
\hline 1 & & Rod & + & + & & + & + & \\
\hline 2 & Swarming & Rod & - & - & & + & - & \\
\hline 3 & & Rod & - & - & & + & - & \\
\hline 4 & & Coccus & + & - & & + & - & \\
\hline 5 & & Rod & + & - & & + & + & + \\
\hline 6 & Non pigmented & Rod & + & + & & + & + & \\
\hline 7 & Translucent, non pigmented & Rod & - & + & & + & + & \\
\hline 8 & & Rod & - & & & + & - & \\
\hline 9 & Light red & Coccus & + & + & & + & + & \\
\hline 10 & Opaque, white/creamy & Coccus & + & - & + & + & - & \\
\hline 11 & Brownish/pink/red & Rods & + & - & & + & - & \\
\hline 12 & Chalky/velvety/purple & Rods & + & - & & - & + & \\
\hline 13 & & Rod & - & + & & + & - & \\
\hline 14 & Mucoid, cream, rough & Coccobacilli & + & + & & + & - & \\
\hline 15 & Entire, low converse & Rods & + & - & & + & - & \\
\hline 16 & & Rods & + & + & & - & + & \\
\hline 17 & & Rods & + & + & & - & + & \\
\hline 18 & & Rods & + & + & & + & - & \\
\hline
\end{tabular}




\begin{tabular}{|c|c|c|c|c|c|c|c|c|}
\hline Isolate & $\begin{array}{l}\text { Cultural } \\
\text { Characterization }\end{array}$ & $\begin{array}{l}\text { Morphological } \\
\text { Characteristics } \\
\end{array}$ & Gram stain & Spore stain & Coagulase & Catalase & Oxidase & Urease \\
\hline 19 & & Rods & + & - & & + & + & + \\
\hline 20 & & Rods & + & + & & + & + & \\
\hline 21 & & Rods & + & + & & - & - & \\
\hline 22 & Green & Rods & + & - & & + & & \\
\hline 23 & Cream & Rods & - & - & & + & - & \\
\hline 24 & Purple pigmented colonis & Rods & - & - & & + & - & \\
\hline
\end{tabular}

Table 3. Continue.

\begin{tabular}{|c|c|c|c|c|c|c|c|c|}
\hline Isolate & Citrate & Acid fast & $\mathrm{H}_{2} \mathrm{~S}$ & Motility & Glucose & Lactose & Gas prod & bacteria \\
\hline 1 & + & & - & + & + & + & + & Bacillus \\
\hline 2 & & & + & + & + & + & + & Pseudomonas \\
\hline 3 & + & & + & + & + & + & + & Protteus \\
\hline 4 & + & & - & + & + & - & - & Marrnococcus \\
\hline 5 & + & & + & + & + & - & - & Alkaligenes \\
\hline 6 & & & + & - & - & + & + & \\
\hline 7 & + & & + & - & - & - & - & Flavobacteruim \\
\hline 8 & + & & + & + & + & + & + & Citrobacter \\
\hline 9 & - & & + & - & - & - & - & Micrococcus \\
\hline 10 & - & & - & - & - & - & - & staphylococcus \\
\hline 11 & + & + & + & & - & - & - & Gordona \\
\hline 12 & - & + & + & + & - & - & - & Norcadia \\
\hline 13 & + & & + & + & - & - & - & Agremona \\
\hline 14 & + & + & + & & - & - & - & Rhodococcus \\
\hline 15 & + & - & - & + & + & + & + & Listeria \\
\hline 16 & + & & + & + & + & - & + & sporosarcinia \\
\hline 17 & - & + & + & + & + & + & + & Clostridium \\
\hline 18 & + & & + & - & + & + & + & Sulfidobacillus \\
\hline 19 & & - & + & - & + & + & + & Corynebacterium \\
\hline 20 & - & & - & + & - & + & + & \\
\hline 21 & + & & - & + & + & + & + & Amphibacillus \\
\hline 22 & + & & + & + & + & + & + & Chlorobium \\
\hline 23 & + & & - & + & - & - & - & Acinetobacter \\
\hline 24 & + & & - & + & & - & - & Rhodopseubomonas \\
\hline
\end{tabular}

Table 4. Biochemical characteristics of crude oil degraders in the study.

\begin{tabular}{|c|c|c|c|c|c|c|c|c|}
\hline Isolate & Cultural Characteristics & $\begin{array}{l}\text { Morphological } \\
\text { Characteristics }\end{array}$ & $\begin{array}{l}\text { Gram } \\
\text { stain }\end{array}$ & $\begin{array}{l}\text { Spore } \\
\text { stain }\end{array}$ & Coagulast & Catalase & Oxidase & Urese \\
\hline 1 & & Coccus & + & - & & + & - & \\
\hline 2 & Non pigmented, smooth entire & Coccus & + & - & & + & - & \\
\hline 3 & Swarmy & Rods & - & + & & + & - & \\
\hline 4 & Smooth, converse, yellow & Coccus & - & - & & + & - & \\
\hline 5 & Entire, colourless, pulvinate & Rods & & + & & + & - & \\
\hline 6 & & Rods & - & - & & + & - & \\
\hline 7 & Irregular, non pigmented, smooth & Coccus & + & - & & + & - & \\
\hline 8 & Pigmented yellow- red & Coccus & + & - & & + & - & \\
\hline 9 & Low converse, translucent, grey & Rod s & + & - & & + & - & \\
\hline 10 & & Rods & + & - & & + & - & \\
\hline 11 & Cream coloured & Rods & + & + & & + & - & \\
\hline 12 & Swarmy & Rods & - & - & & + & - & \\
\hline 13 & Creamy-orange & Rods & + & + & & + & - & \\
\hline 14 & & Rods & + & - & & + & - & \\
\hline 15 & & Coccoba callus & + & - & & + & - & \\
\hline 16 & & Rods & + & + & & + & - & \\
\hline 17 & Opaque whitish & Cluster Coccus & + & - & + & + & - & \\
\hline 18 & Yellowish & Coccus & + & - & & + & - & \\
\hline 19 & & Rods & + & - & & + & + & \\
\hline 20 & & Rods & + & - & & & - & \\
\hline 21 & Circular, opaque, converse, granular & Coccus & - & - & & + & - & \\
\hline 22 & & Rods & - & - & & + & - & \\
\hline 23 & & Rods & + & + & & - & + & \\
\hline 24 & Yellowish & Coccus & + & - & & + & - & \\
\hline 25 & Mucoid, cream & Coccobacillus & + & - & & + & - & \\
\hline 26 & & Rods & + & - & & - & - & \\
\hline
\end{tabular}


Table 4. Continue

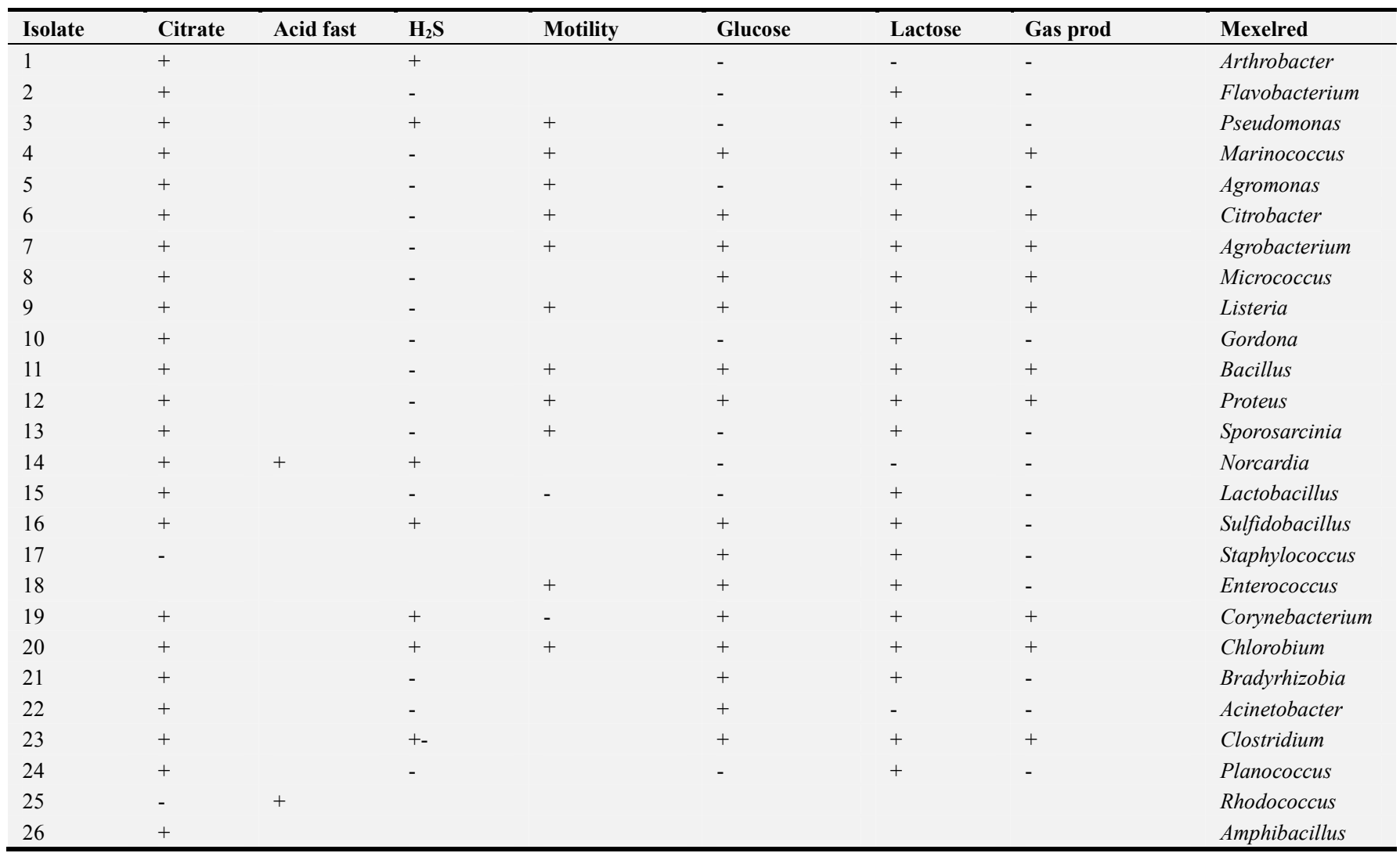

Table 5. Microbial succession observed in the study.

\begin{tabular}{|c|c|c|c|}
\hline THB & HUB & HUAB & FE \\
\hline Escherichia & Escherichia & Bacillus & Trichosporum $\mathrm{sp}$ \\
\hline Citrobacter & Citrobacter $\mathrm{sp}$ & Clostridium & Aspergillus terreus \\
\hline Pseudomonas & Pseudomonas & Plannococcus & Aspergillus oryzae \\
\hline Burkholderia & Burkholderia & Amphibacillus & Acremonium kilenis \\
\hline Salmonella sp & Salmonella sp & Kurthia & Aspergillus flavies \\
\hline Shigilla sp & Shigella $\mathrm{sp}$ & Jonesia & Mucor $\mathrm{sp}$ \\
\hline Flavobacterium & Agrobacterium sp & & Fusarium sp \\
\hline Micrococcus sp & Micrococcus sp & & Candida $\mathrm{sp}$ \\
\hline Agromonassp & Listeria $\mathrm{sp}$ & & \\
\hline Sporosarcinia $\mathrm{sp}$ & Bacillus sp & & \\
\hline Clostridium sp & Sporosacinia sp & & \\
\hline Sulfidobaccllus sp & Staphylococcus sp & & \\
\hline Gorgona sp & Enterococcus sp & & \\
\hline Norcardia sp & Planococcus sp & & \\
\hline Rhodococcus sp & Flavobacterium $\mathrm{sp}$ & & \\
\hline Chlorobium $s p$ & Amphibacillus sp & & \\
\hline Rhodopseudomonas sp & Agromonas sp & & \\
\hline \multirow[t]{5}{*}{ Acinetobacter sp } & Sulfidobacilus sp & & \\
\hline & Rhodococcussp & & \\
\hline & Chlorobium $s p$ & & \\
\hline & Rhodopseudomonas sp & & \\
\hline & Acinetobacter sp Lactobacillus sp & & \\
\hline
\end{tabular}

THB: Total Heterotrophic Bacteria; HUB: Hydrocarbon Utilizing Bacteria; HUAB: Hydrocarbon Utilizing Anaerobic Bacteria; FE: Fungi Encountered 


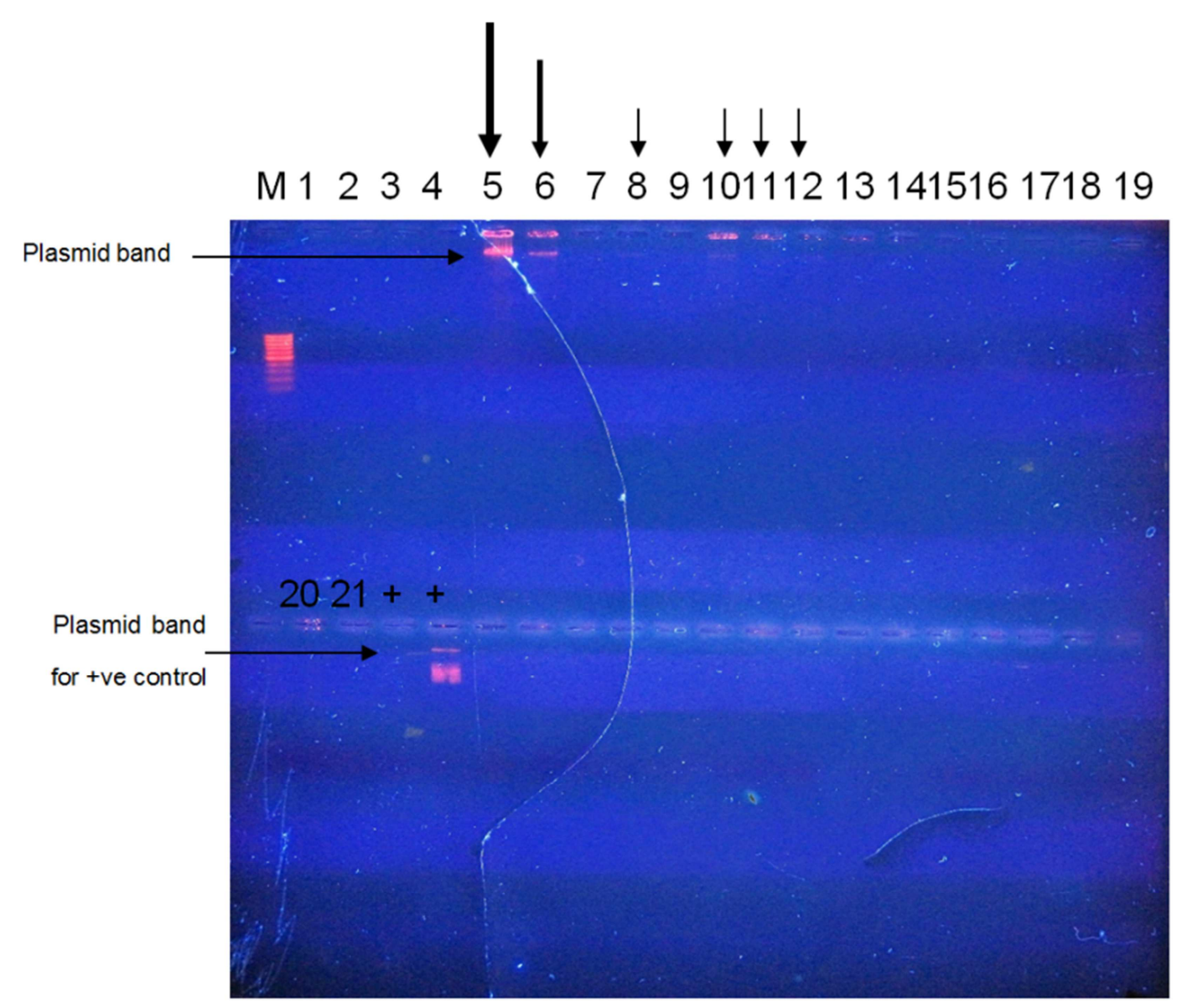

Figure 4. Electrophoretic separation profile of plasmid DNAs from strains of Agromonas, Agrobacterium, Listeria, Sporosarcinia, Lactobacillus and Staphylococcus spp. Lines 5, 6, 8,10,11 and 12 bear plasmid of different band sizes and intensity.

\section{Discussion}

This study looked at the effects and potentials of rhizosphere microorganisms in the degradation of petroleum products in the following sites; four single plant plots, a mixed plant species plot, two oil wells plots and a nonrhizosphere plot. The field samples were collected from Kpopie and Korokoro communities of Ogoni, Rivers State, Nigeria. Pollution in this area is high and chronic, and spillage of petroleum product is more than 50 years old. Table 1 shows the physicochemical parameters of soil samples from the hydrocarbon-contaminated field soils of Ogoni. Most of the soil studied were acidic. Samples A and B had low $\mathrm{Cu}^{2+}$ content (Trace) while sample D (Mixed Plant species plot) had as high as $72 \mathrm{mg} / \mathrm{kg}$. $\mathrm{Cu}^{2+}$ content of samples $\mathrm{G}, \mathrm{H}$ and Control fell within the normal range of 15 $-30 \mathrm{mg} / \mathrm{kg}$. All soils of study had high $\mathrm{Pb}^{2+}$ and $\mathrm{Fe}^{2+}$ content. There was significant difference between the physicochemical parameters over the various soil samples $\mathrm{P}$ $<0.028<0.05$. Also significant differences exist between the various physicochemical parameters within the various soil samples, P-value $=0.00<0.05$. Table 2 shows the hydrocarbon status of the field samples as well as the microbial population changes during rhizoremediation. The TPH of soil from the field study of kpopie and korokoro fluctuated between 56 and 4, 650. $13 \mathrm{mg} / \mathrm{kg}$. Significant difference existed between the plots. In all, the soil plot containing mixed plant species had the lowest TPH concentration of $56 \mathrm{mg} / \mathrm{kg}$, while soil sample E, oil well 3, korokoro without vegetation had the highest TPH concentration. There was no significant difference between TPH of the mixed population and that of the control. It is clear that there has been co-metabolism whereby the different plant species had given rise to a net high mineralization rate. This is in concordance with studies of Reilley et al., [29]; Aprill, and Sims [2], Daane et al., [9]; Kirk et al., [13] and Siciliano et al., [30]. It is also evident that sample D, the mixed plant species plot also gave the lowest PAH concentration of 0.314. This value is close to the PAH concentration of the control sample, Results obtained in table 2 shows that microbial abundance and activity have a corresponding effect on hydrocarbon degradation. There was more reduction of TPH in the mixed plant species plots of both experimental $(2.88 \mathrm{mg} / \mathrm{kg})$ and field site $(56 \mathrm{mg} / \mathrm{kg})$, and in the PAH $(0.314 \mathrm{mg} / \mathrm{kg})$ in the field study. This finding agrees with studies of Yateem et al., [37], in their study; they recorded that the total hydrocarbons in a diesel contaminated soil decreased faster in the presence of roots and nutrients compared to that in a non-vegetated soil.

Table 2 shows that specific local plants promote increased net hydrocarbon degradation. Table 4 shows that, of the 26 crude oil degrading bacteria isolated, 19 were Gram-Positive. 
Although some studies have shown that oil-polluted soils are dominated by Gram-negative bacteria ([17]; [15]). The dominant culturable hydrocarbon utilizing bacteria in both experimental and field plots of this study were made up of both Gram positive and Gram-negative bacteria; Gordona, Rhodococcus, Corynebacterium, Norcardia, Arthrobacter Spp. etc. This corroborates with the findings of Quatrini et al., [26], who isolated Rhodococcus, Gordona and Norcardia strains as the dominant hydrocarbon degraders from a hydrocarbon-contaminated mediterrenean shoreline. Grass root system in the two studies undertaken demonstrated higher degradation potential than the other plants of study. According to Aprill, and Sims [2] grass root system has the maximum root surface area per $\mathrm{m} 3$ of the soil than any plant type and may penetrate the soil to a depth of $3 \mathrm{~m}$.

Results of Boganet al., [4];Margesim, and Schinner [19], and Hamamura [10] demonstrated the prevalence of Actinobacteria in hydrocarbon polluted soils from different geographical locations, their various studies also demonstrated the presence of multiple hydrocarbon catabolic genes in this group of bacteria. This study however recorded a mixture of microbial consortium involving both Gram positive and Gram-negative bacteria, and aerobic and anaerobic bacteria. The bacterial population dynamics and counts observed during crude oil degradation could also be associated with the degradation patterns of the total petroleum hydrocarbon (TPH) and polycylic aromatic hydrocarbon (PAH) in the different plots.

All bacteria isolated from this study are indigenous and all survived petroleum hydrocarbon contamination, they adapted to oil-contaminated soil easily as reported by other authors ([28]; [31]). This was evident in samples collected from the chronic contaminated soils of Ogoniland. Figure 4 illustrates that some of the bacteria isolated from this study contained plasmid DNA that could be responsible for crude oil degradation; regrettably this study did not carry out amino acid sequencing/comparison. Plasmid bands were found in 6 organisms; Agromonas, Agrobacterium, Listeria, Sporosarcinia, Lactobacillus, Staphylococcus spp. This study is in concordance with the study of Kiyohara, and Nagao [14] who recorded phenanthrene degradation genes in plasmids of different strains of Comamanas testosteroni, Beijerinckia and Alkaligene faecalias AFK2. Plasmid bands were not recorded in organisms isolated pre-contamination. This is in agreement with studies by many authors that maintain that microorganisms' genes; $\mathrm{Pp}$ alk $\mathrm{B}, \mathrm{Rh}$ alk $\mathrm{B} 1$, and Rh alk $\mathrm{B} 2$ genes etc., borne on plasmid DNA are responsible for petroleum-oil biodegradation ([36]; [19]).

Endophytic organisms were found to be in abundance in this study in the $10^{6}$ range. VanAkenet al. [35], suggested that endophytes may have potential for remediation of environmental soil containing explosives. Also, Sicilianoet al.,[30] identified 34 bacterial strains as having potential to enhance bioremediation of contaminated environmental soil. Daane et al. [9] observed that plasmid DNA contain degradative genes capable of degrading the most complex, the most recalcitrant and the most synthetic molecules. This study has shown that rhizoremediation can contribute to the restoration of polluted sites and is in consonance with reports from several authors [27].

\section{Conclusion}

This study has been able to use specific local Nigerian plants like elephant grass, carpet grass, palm tree, Indian bambo and fern to promote the rhizoresssmediation of crude oil-polluted soils.

Effective indigenous microorganism (EIM) that gave rise to the net mineralization of polycyclic aromatic hydrocarbons (PAHs) and total petroleum hydrocarbon (TPH) include members of the Genera Flavobacterium, Pseudomonas, Sporosarcinia, Listeria, Bacillus, Proteus, Lactobacillus, Staphylococcus, Bradyrhizobia, Enterococcus, Planococcus, Rhodococcus Clostridium, Amphibacillus, Kurthria, Jonesia and Agromonas. DNA of Agromonas, Agrobacterium, Listeria, Sporosarcinia, Lactobacillus, and Staphylococcus contain plasmids that could be responsible for the rhizoremediation of crude oilpolluted soil.

Endophytic communities took part in the net mineralization of crude oil - Pseudomonas and Arthrobacter spp. Anaerobic microbial communities also contributed to the overall degradation potential of this study. The anaerobes encountered include; Bacillus, Clostridium, Amphibacillus, Kurthria and Jonesia Spp. A mixed population of the above mentioned plants gave rise to increased net hydrocarbon degradation in the studies conducted. Both bacterial abundance and plant community composition impacted on hydrocarbon degradation potential.

Composition of microbial community in a rhizosphere differs both quantitatively and qualitatively. The total petroleum hydrocarbons (TPH) in the crude oil contaminated soisl decreased faster in the presence of roots and nutrients compared to non-vegetated soils and decreased even faster in the soil plots containing mixed plant species.

The study recorded more mineralization of polyaromatic hydrocarbons than the straight chain hydrocarbons. The rhizosphere microorganisms encountered in this study were able to mineralize the following components of crude oil; naphthalene, acenapthalene, acenaphthylene, fluorene, phenanthrene, anthracene, fluoranthene, pyrene, benzo(a)anthracene, chrysene, benzo (b) fluoranthene, indeno(1,2,3-cd) pyrene, benzo(k) fluoranthene, benzo (B)fluorathene, debenzo $(\mathrm{a}, \mathrm{h})$ anthracene, bezo $(\mathrm{g}, \mathrm{h}, \mathrm{l}$ ) perylene.

Studies of microbial consortia are of great importance for best understanding of biodegradation process, the ability to determine the alkane degradative composition of a microbial soil community should also help develop appropriate bioremediation strategies.

\section{Recommendation}

i Rhizoremediation, a combination of phytoremediation 
and bioaugmentation which makes use of rhizosphere microorganisms is recommended as the best treatment option for hydrocarbon clean-up.

ii A mixture of specific plant, population abundance of effective indigenous microorganism could be developed as an appropriate technology to tackle environmental problem and mitigate the effects of ecological disasters in Nigeria.

iii Serious efforts should be made to avert the devastating effect of crude oil on cassava staple food in Nigeria.

iv Government should sponsor research work so that studies as this will have enough fund to carry out more intensive genetic studies on organisms that bear plasmids in order to characterize and sequence the genes responsible for hydrocarbon degradation.

v Efforts should be made to collect and store (bank) these rhizosphere microorganisms, so that they could be manipulated for efficient degradation. These can be interesting tools to further improve and develop rhizoremediation into a widely accepted technique.

vi Studies are required to decipher the particular genes borne on the plasmids demonstrated from these isolates in order to develop them genetically and make room for more cost-effective rhizoremediation schemes.

vii Metabolically active microbial communities that played role in hydrocarbon degradation in this study are numerous, in addition to routine microbiological methods, this study recommends that funding will allow for molecular methods of identification e.g., metagenomics analysis which promises enormous potential for identifying novel enzymes and pathways involved in the biodegradation of poorly and inefficiently degraded pollutants, in order to capture more of these organisms.

viii It is recommended that a follow-up study be undertaken to ascertain the roles played by each microorganism in the clean-up exercise since this study has shown that a net effect of the activities of all interacting microorganisms were responsible for the crude oil-degradation.

\section{References}

[1] Ayotamuno, M. J., Kogbara, R. B. and Ogaji, S. O. T. (2008). Bioremediation of crude oil polluted agricultural soil at Port Harcourt, Nigeria. Applied Energy 8 (11): 1249-1257.

[2] Aprill, W. and Sims, R. C. (1990). Evaluation of the use of prairie grasses for Stimulating Polycyclic aromatic hydrocarbon treatment in soil. Chemosphere 20 (1-2): 253265 .

[3] APHA (1998). Standard Methods for Examination of Water and Waste Water. $20^{\text {th }}$ ed. APHA-AWWA/WPCP. Washington D C.

[4] Bogan, B. W. Lahner, L. M., Sullivan, W. R. and Patere, K. J. R (2003). Degradation of straight chain aliphatic and high molecular weight polycyclic aromatic hydrocarbons by a strain of Mycobacterium austroafricarium. Journal of Applied Microbiology 94: 230-239.

[5] Brand, J., Lugtenberg, B. J. J., Glandorf, D. C. M., Bakker, P. A. H. M., Schippers, B., and de Weger, L. A. (1990). Isolation and characterization of a superior potato root-colonizing Pseudomonas strain. In: Plant Growth Promoting Rhizobacteria-Progress and Prospects. C. Keel, B. Koller, and G. De'fago, eds. IOBC/WPRS Bull. XIV-8. Interlaken, Switzerland. Pp 350-354.

[6] Cheesbrough, M (2000). Biochemical testing of Microorganisms In: Medical Laboratory Manual for Tropical Countries. Vol 11: Microbiology. Pp 58 - 69.

[7] Chiapusio, G., Pujol, S., Toussaint, M. L., Badot, P. M., and Binet, P. (2007). Phenanthrene toxicity and dissipation in rhizosphere of grassland plants (Loliumperenne L. and Trifoliumpratense L.) in three spiked soils. Plant Soil 294:103-112.

[8] Chikere, C. B., Okpokwasili, G. C. and Chikere, B. O. (2009). Bacterial diversity in a tropical crude oil polluted soil undergoing bioremediation. African Journal of Biotechnology. 8 (11): $2535-2540$.

[9] Daane, L. L., Harjono. I., Zylstra, G. J. and Häggblom, M. M. (2001). Isolation and characterization of polycyclic aromatic hydrocarbon-degrading bacteria associated with the rhizosphere of salt marsh plants. Applied Environmetal Microbioliology 67: 2683-2691.

[10] Hamamura, N., Oslon, S. H., Ward, D. M. and Inskeep W. P (2006) Microbial population dynamics- associated with crude oil biodegadation in diverse soils. Applied Enviromental Microbiology. 72: 6316- 6324.

[11] Jobson, A., McLauglin, M., Cook, F. D. and Westlake, D. W. S. (1974). Effects of amendments on the microbial utilization of oil appliced to soil. Applied Microbiology, 27: 166-171.

[12] Kirk, J. L., Beaudette, L. A., Hart, M., Moutoglis, P., Klironomos, J. N., Lee, H. and Trevors, J. T. (2004). Methods of studying soil microbial diversity. Journal of Microbiological Methods 58: 169-188.

[13] Kirk, J. L., Klironomos, J. N., Lee, H. and Tervors, J. T. (2005). The effects of perennial ryegrass and alfalfa on microbial abundance and diversity in petroleum contaminated soil. Environmental Pollution 133: 455-465.

[14] Kiyohara, H., and Nagao, K. (1977). Enzymatic conversion of 1-hydroxyl -z-napthoate in phenanthere-grown Aeromonas sp. 545PI. Agricultural. Biolology and Chemistry 41:705.

[15] Kuiper, I., Kravchenko, L. V., Bloemberg, G. V., and Lugtenberg, B. J. J. (2003). Pseudomonas putida Strain PCL 1444, selected for efficient root colonizatioand naphthalene degradation, effectively utilizes root exudate components. Molecular Plant Microbe, 15:734-741.

[16] Liste, H. H. and Prutz, I. (2006). Plant performance, dioxygenase-expressing rhizosphere bacteria, and biodegradation of weathered hydrocarbons in contaiminated soil. Chemosphere 62: $1411-1420$.

[17] Macnaughton, S. J., Stephen, J. R., venos a A. O., Davis, G. A., Chang, Y. J. and White, D. C (1999). Microbial population changes during biovemediation of an experimentally oil spill. Applied Environmental Microbiology. 65: 3566-3574. 
[18] Macnaughton, S. J., Stephen, J. R., venos a A. O., Davis, G. A., Chang, Y. J. and White, D. C (1999). Microbial population changes during biovemediation of an experimentally oil spill. Applied Environmental Microbiology. 65: 3566-3574.

[19] Margesim, R and Schinner, F. (2001). Bioremediation (natural attenuation) and Biostimulation) of diesel oil-contaminated soil in an alpine glacier sking area. Applied Environmental Microbiology. 67(7): 3127.

[20] Margesim, R and Schinner, F. (2001). Bioremediation (natural attenuation) and Biostimulation) of diesel oil-contaminated soil in an alpine glacier sking area. Applied Environmental Microbiology. 67(7): 3127.

[21] Mills, A. L., Breuil, C., and R. R. Colwell (1978). Enumeration of petroleum degrading marine and estuarine microorganisms by the most probable number method. Canadian Journal of Microbiology. 24: 552 - 557.

[22] Okpokwasili, G. C. and Odokuma, L. O. (1994). Tolerance of Nitrobacter to toxicity of some Nigerian crude oils. Bulletin of Environmental Contamination and Toxicology, 52: 388-395.

[23] Okpokwasili, G. S. C. (2006). Microbes and the environmental challenge. University of Port Harcourt Press, Port Harcourt. Inaugural lecture series No. 53.

[24] Okpokwasili, G. S. C. and Okorie, B. B. (1988). Biodegradation potentials of microorganisms isolated from car engine lubricating oil - Trib International. 21: 215-220.

[25] Philip, L. A. (2008). The relationship between plants and their root-associated microbial communities in hydrocarbon phytoremediation systems. University of Saskatchewan, Saskatcheian, S7N 5A8. Ph.D thesis.

[26] Quatrini, P., Scaglione, G., De Pasquale, C., Rella, S. and Puglia, A. M. (2008). Isolation of Gram-positive n- alkane degrade from hydrocarbon contaminated mediterevenean shore line. Journal of Applied Microbiology. 104: 251- 259.

[27] Reddy, B. R. and Sethumathan, N. (1994). Mineralization of p-nitrophenol in the rhizosphere of rice. Agricultural Ecosystem Environvironment 47: 313-317.

[28] Rehman, K., Noll, H. T., Steinberg, C. E. and Kettrup, A. A.
(2003). Pyrene Degradation by Mycobacterium sp. Strain KR2. Chemosphere 36: 2977.

[29] Reilley, K. A., Banks, M. K. and Schwab, A. P. (1996). Organic chemicals in the environment: dissipation of polycyclic aromatic hydrocarbons in the rhizosphere. Journal of Environmental Quality. 25: 212-219.

[30] Siciliano, S. D., Germida, J. J. and Greer, C. W. (2003). Changes in microbial community composition and function during polyaromatic hydrocarbon phytoremediation field trial. Applied and Environmental Microbiology, 69:483-489.

[31] Sugiura, K., Ishihara, M., Shimauchi, T. and Harayama, S. (1997) Physiochemical properties and biodegradability of crude oil. Environmental Science and Technolnology 31: 4551 .

[32] Talaro, K. P. and Talaro, A. (1998). Foundations in Microbiology. ISBN $-10: 0697354520, \quad I S B N-13$ 9780697354525McGrawhillCompannies.

[33] U.S. Environmental Protection Agency (2007). New test methods online. Extraction of Solid and Aqueus Samples for Chemical Agents. July, 2007. www.usepa.govhttp//www.epa.gov/osw/hazard/testmethods/sw 846/new meth.htm $\# 3572$

[34] Umeaku, C. N. (2008). Biochemical Testing of Microorganisms In: Laboratory Practice for Tertiary Institutions. Odus Press, Enugu. ISBN 978-38379-7-4.

[35] Van Aken, B., Peres, C., Doty, S., Yoon, L. and Schnoor, J. (2004). Methylobacteriumpopuli specie, a novel aerobic, pinkpigmented, facultative methylotrophic, methane-utilising bacterium isolated from poplar trees (Populus deltoids $x$ nigra DN 34). Evolution Microbiology 54: 1191-1196.

[36] White Jr, P. M., Wolf, D. C., Thoma, G. J. and Reynolds, C. M. (2002). Phytoremediation of alkylated polycyclic aromatic hydrocarbons in a crude oil-contaminated soil. Water, Air, Soil Pollution 169: 207-220.

[37] Yateem, A., M. T. Balba, A. S. El-Nawawy and N. Al-Awadhi, (2000). Plants-associated Microflora and the remediation of oil contaminated soil. International Journal of Phytoremediation 2: 183-191. 